\title{
Effect of thickness and substrate temperature on structure and optical band gap of hot wall-deposited CuInSe 2 polycrystalline thin films
}

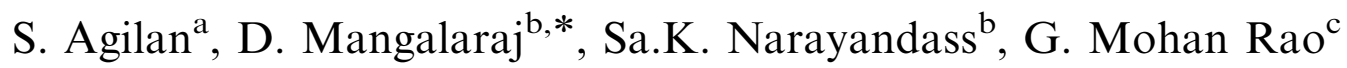 \\ ${ }^{a}$ Department of physics, Coimbatore Institute of Technology, Coimbatore 641 014, India \\ ${ }^{\mathrm{b}}$ Thinfilm Laboratory, Department of Physics, Bharathiar University, Coimbatore 641 046, India \\ ${ }^{\mathrm{c}}$ Department of Instrumentation, Indian Institute of Science, Bangalore 560 012, India
}

\begin{abstract}
The copper indium di selenide $\left(\mathrm{CuInSe}_{2}\right)$ compound was prepared by direct reaction of high-purity elemental copper, indium and selenium. $\mathrm{CuInSe}_{2}$ thin films were prepared on to well-cleaned glass substrates by hot wall deposition technique. The X-ray diffraction studies revealed that all the deposited films are polycrystalline in nature, single phase and exhibiting chalcopyrite structure. The crystallites were found to have a preferred orientation along the (1 112$)$ direction. The SEM analysis indicated that the films are polycrystalline in nature. The composition of the chemical constituents present in the deposited $\mathrm{CuInSe}_{2}$ thin films has been determined using energy dispersive X-ray analysis (EDX). Structural parameters of $\mathrm{CuInSe}_{2}$ thin films coated with higher substrate temperatures were also studied. As the substrate temperature increases the grain size increases. Simultaneous TG-DTA analysis has been done for CuInSe ${ }_{2}$ bulk and an endothermic reaction is observed near the melting point of the compound. Optical transmittance spectrum of the hot wall-deposited $\mathrm{CuInSe}_{2}$ thin films of different thicknesses deposited at three different substrate temperatures were obtained. As the thickness of the film and the substrate temperature increases, the optical band gap decreases. The refractive index of the $\mathrm{CuInSe}_{2}$ thin films are found decreasing with the incident photon wavelength.
\end{abstract}

PACS: 68.55.j; 78.66.h

Keywords: Hot wall deposition; CuInSe ${ }_{2}$ thin films; Structural; Optical band gap

\footnotetext{
*Corresponding author. Tel.: + 914222425458 ; fax: +91422422387.

E-mail address: dmraj800@yahoo.com (D. Mangalaraj).
}

\section{Introduction}

Copper indium di selenide $\left(\mathrm{CuInSe}_{2}\right)$ is a promising material for thin film solar cells because 
of its extraordinary radiation stability [1]. $\mathrm{CuInSe}_{2}$ is a semiconducting compound which belongs to I-III-VI ${ }_{2}$ chalcopyrite family. It is convenient to view the chalcopyrite structure in terms of two interpenetrating sub lattices in which I-III atomic positions which act as cations rest on the other sublattice [2]. CuInSe $\mathrm{Silms}_{2}$ possess certain exceptional material characteristics like band gap, absorption coefficient and minority carrier diffusion length which are particularly suitable for photovoltaic applications. They can be prepared with n- and p-type conductivity and therefore both homojunction and heterojunction potential exists for this material [3]. The relation between the energy gap and the lattice constant of isovalent chalcopyrite materials and the material requirements for CIS solar cells are analysed by Konovalov [4]. CuInSe 2 thin films have been deposited by several techniques like sputtering [5], molecular beam epitaxy [6], two stage process [7] and vacuum evaporation [8] and so on.More homogeneous and larger area $\mathrm{CuInSe}_{2}$ thin films have been deposited by simple CSVT technique [9].

Hot wall epitaxy has become a popular and reliable technique among different techniques available for the deposition of thin films. Hot wall deposition method yields high-quality epitaxial thin films with smooth surfaces under conditions very close to thermo dynamical equilibrium. Hot wall-deposited CdTe thin films exhibited superior luminescence properties when compared to MBE and MOCVD films [10].

In the present study, stoichiometric $\mathrm{CuInSe}_{2}$ thin films have been deposited on to well-cleaned glass plates by hot wall deposition technique. Hot wall-deposited $\mathrm{CuInSe}_{2}$ thin films are structurally characterized. The dependence of optical band gap of $\mathrm{CuInSe}_{2}$ films with the thickness and the substrate temperature have not been extensively studied so far. Hence, an attempt is made to study the dependence of optical band gap of hot wall-deposited $\mathrm{CuInSe}_{2}$ films with thickness and substrate temperature. The refractive index and extinction coefficient of $\mathrm{CuInSe}_{2}$ thin films have been evaluated and the results are discussed.

\section{Experimental technique}

Bulk CuInSe 2 compound has been synthesized by direct reaction of high-purity $(99.999 \%)$ elemental copper, indium and selenium. Stoichiometric amounts of the elements $\mathrm{Cu}$, In and Se were placed in a quartz ampoule in which a pressure of $3 \times 10^{-5}$ Torr was achieved and then sealed. The ampoule was heated gradually at the rate of $100 \mathrm{~K} /$ $\mathrm{h}$ in steps up to $1430 \mathrm{~K}$ and it was maintained at this temperature for $24 \mathrm{~h}$ and then allowed to cool slowly to room temperature. During the course of heating and cooling the quartz ampoule was rotated continuously to ensure homogeneity in the molten mixture. The prepared bulk $\mathrm{CuInSe}_{2}$ compound has been evaporated and deposited onto well-cleaned glass substrates by hot wall deposition technique. The schematic diagram of the hot wall experimental set up is shown in Fig. 1. The main feature of the system is the heated linear quartz tube, which serves

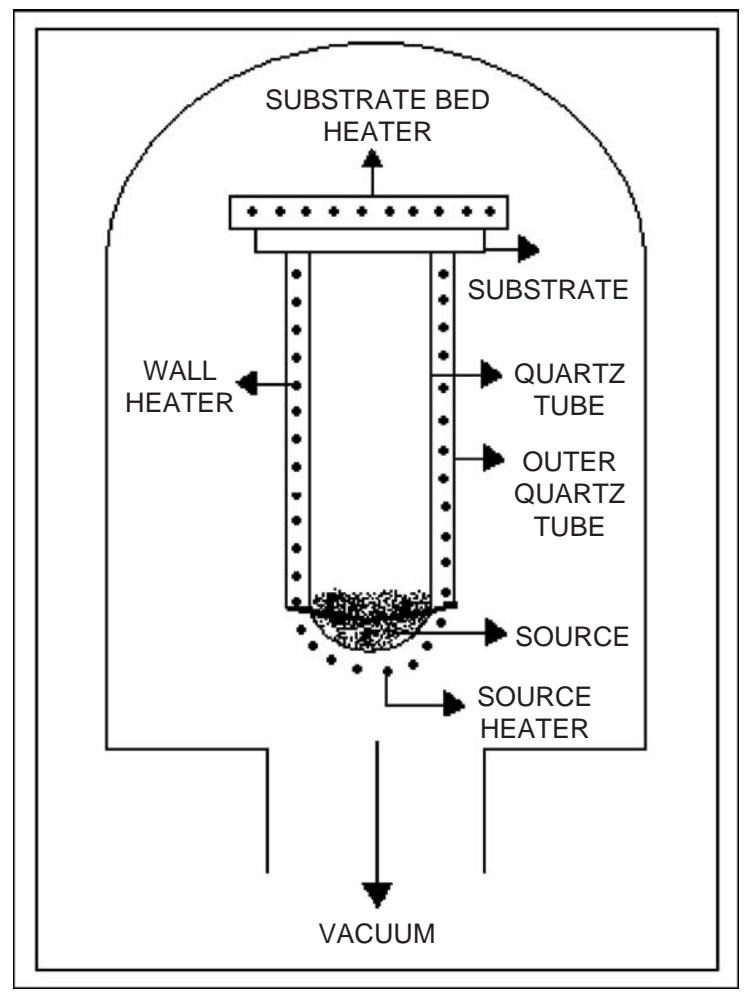

Fig. 1. The schematic diagram of the hot wall experimental set up. 
to enclose and direct the vapour from source to substrate. Kanthal wire wound closely along the length of the quartz tube is used to heat the wall of the quartz tube. Three independent heater coils were used to heat the source, wall of the tube and the substrate. The substrate was held at a distance of less than $1 \mathrm{~mm}$ exactly above the open end of the quartz tube acting almost as a lid closing the tube with the help of a substrate holder cum heater. The outer quartz tube which is almost equal to the length of the wall of the inner quartz tube prevents the thermal flux dissipating out and maintains highuniform thermal flux all along the length of the tube. The quartz tube was charged with the prepared $\mathrm{CuInSe} \mathrm{I}_{2}$ compound and the whole arrangement was placed inside the vacuum chamber in which a pressure of $10^{-5}$ Torr was achieved prior to the growth of the film. CuInSe 2 thin films have been deposited onto well-cleaned glass substrates, using $1 \mathrm{~cm}$ diameter quartz tube of optimized length $11 \mathrm{~cm}$ with the source and wall temperatures around $1270 \mathrm{~K}$. Due to radiation of heat from the hot wall the substrate temperature automatically raised to $370 \mathrm{~K}$ under normal coating conditions. The thicknesses of the films have been determined using gravimetric technique and the same is confirmed by multiple beam interferometry technique. The structure of the films have been studied using X-ray diffractometer Model Philips PW 3710 with $\mathrm{CuK}_{\alpha}$ radiation. The surface topography and estimation of chemical constituent present in the deposited films have been determined using scanning electron microscope attached with energy dispersive X-ray analysis (EDX) Model 7060 Oxford Instruments (Cambridge). Simultaneous TG-DTA analysis were carried out by the TGDTA analyser Model SPT Q 600 (Waters). Optical transmittance spectra were analysed by UV-VISNIR Spectrophotometer Model JASCO V-570 in the wavelength range from 800 to $2500 \mathrm{~nm}$.

\section{Results and discussions}

\subsection{Structural characterization}

Fig. 2 shows the X-ray diffractogram of the prepared $\mathrm{CuInSe}_{2}$ bulk. The sharp peaks present

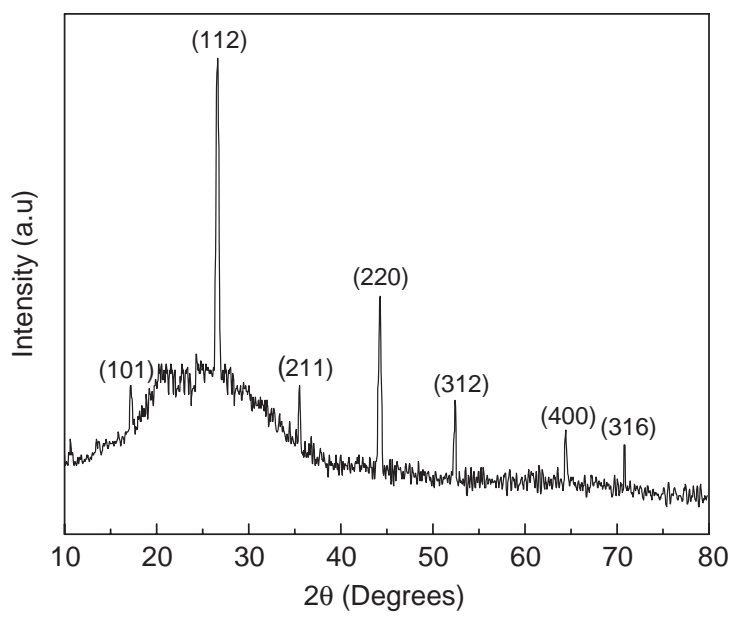

Fig. 2. X-ray diffractogram of the prepared $\mathrm{CuInSe}_{2}$ bulk.

in X-ray diffractogram indicates that the prepared $\mathrm{CuInSe}_{2}$ bulk is polycrystalline in nature. The preferred orientation of the particles are identified along certain crystallographic planes as (1 011$)$, (1 12$)$, (2 111$)$, (220), (312), (400) and (316), confirms the chalcopyrite structure [11]. The lattice parameters ' $a$ ' and ' $c$ ' in the prepared bulk compound have been determined as 5.784 and $11.617 \AA$, respectively and are in good agreement with the ASTM values ( $a=5.782 \AA$ and $11.619 \AA)$.

X-ray diffractogram of $\mathrm{CuInSe}_{2}$ thin films of different thicknesses deposited in the present study is shown in Fig. 3. In the thin films of $\mathrm{CuInSe}$ the preferred orientation of the grains are identified along (1 1 2), (220) and (3 1 2) directions. The (400) orientation is found only in thicker films. The presence of (1 12$)$, (2 2 20$)$ and (3 12 ) diffraction peaks confirm the chalcopyrite structure $[12,13]$. The EDX pattern of the CuInSe ${ }_{2}$ thin film deposited using quartz tube of length $11 \mathrm{~cm}$ is shown in Fig. 4 and indicates the stoichiometry of the deposited $\mathrm{CuInSe} \mathrm{I}_{2}$ thin films.

The X-ray diffraction pattern of $\mathrm{CuInSe}_{2}$ thin films deposited at 423, 523 and $673 \mathrm{~K}$ temperatures are found to exhibit crystalline structure and are shown in Fig. 5.

As the substrate temperature is increased the films are found to show as highly preferred orientation along the (1 112$)$ direction [14]. The $\mathrm{CuInSe}_{2}$ thin films with chalcopyrite structure and 


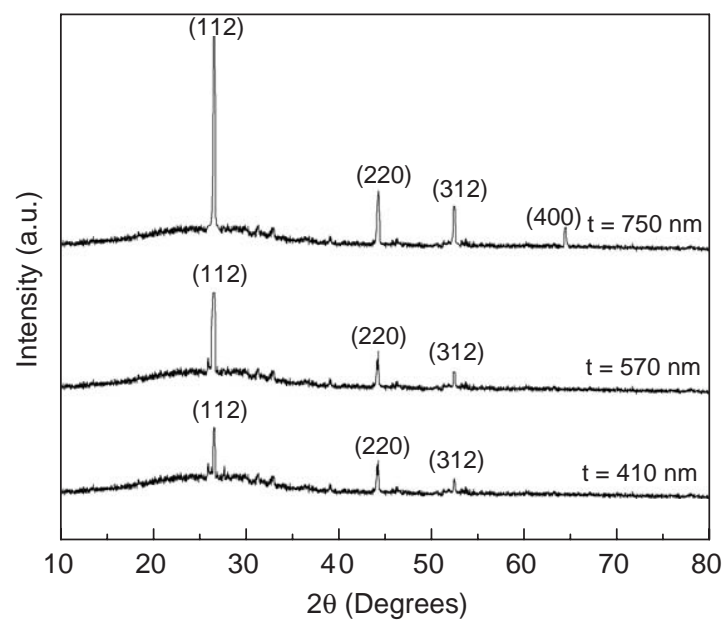

Fig. 3. X-ray diffractogram of $\mathrm{CuInSe}_{2}$ thin films of different thicknesses deposited using quartz tube of length $11 \mathrm{~cm}$.

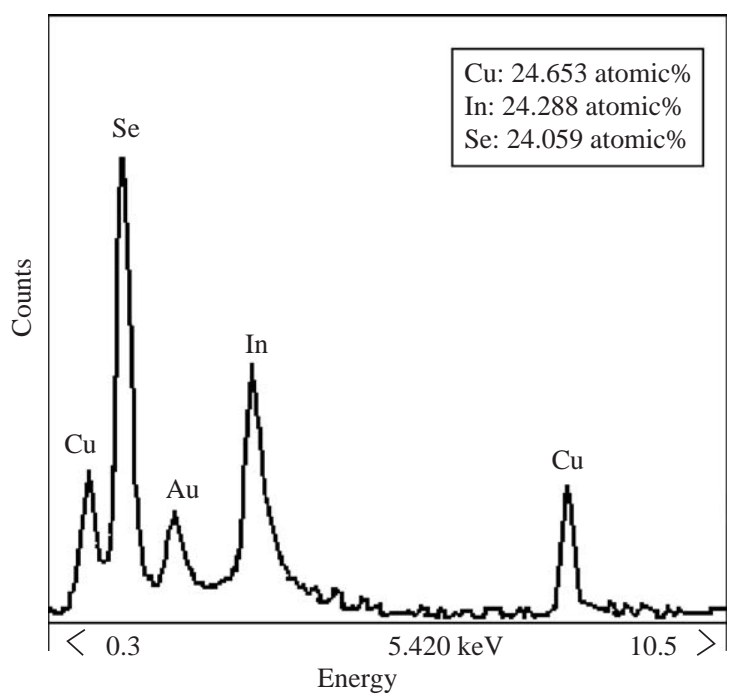

Fig. 4. The EDX pattern of the $\mathrm{CuInSe}_{2}$ thin film deposited using quartz tube of length $11 \mathrm{~cm}$.

having lattice constant $c / a$ ratio equal to 2 as the most suitable one for the fabrication of $\mathrm{CdS} /$ $\mathrm{CuInSe}_{2}$ heterojunction solar cells.

Figs. 6 and 7 are the SEM micrographs of the thin films with thickness $410 \mathrm{~nm}$ as deposited and with substrate temperature $673 \mathrm{~K}$, respectively. The crystallite sizes in the $\mathrm{CuInSe}_{2}$ thin films deposited with thickness $410 \mathrm{~nm}$ is $95 \mathrm{~nm}$ and the

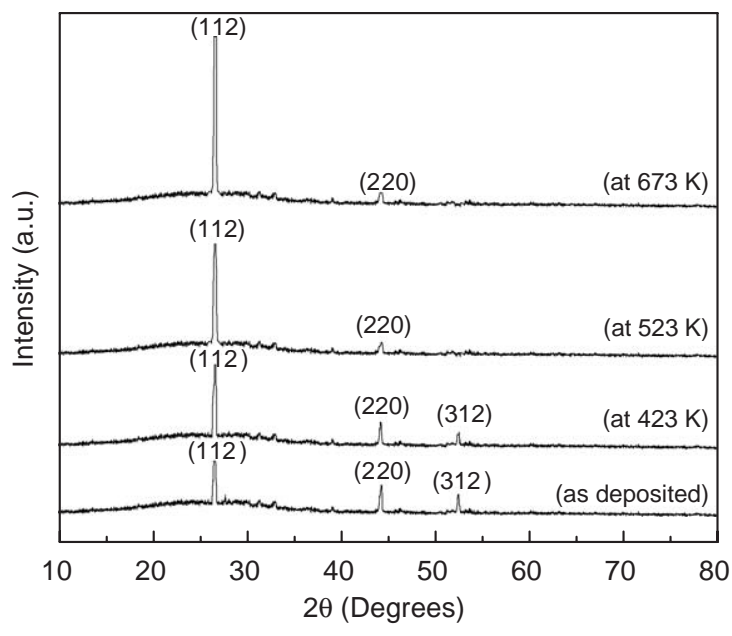

Fig. 5. The X-ray diffraction pattern of $\mathrm{CuInSe}_{2}$ thin films deposited at 423, 523 and $673 \mathrm{~K}$ temperatures.

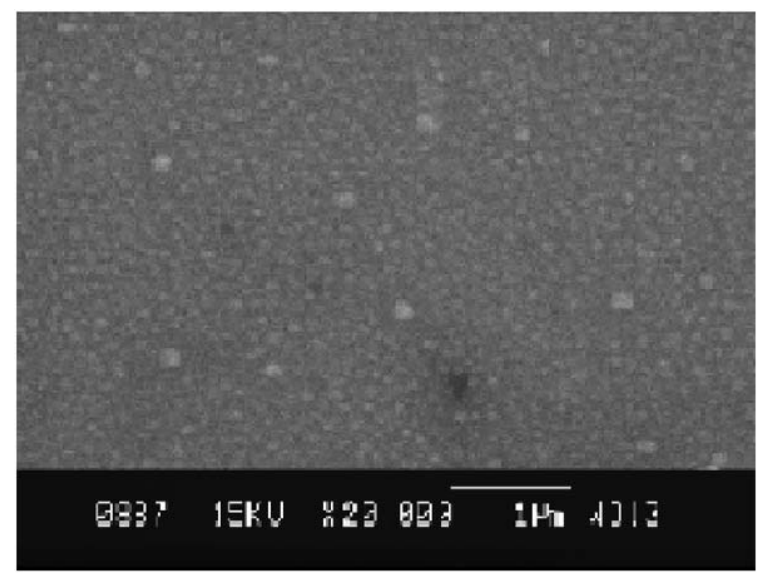

Fig. 6. SEM micrographs of the as-deposited $\mathrm{CuInSe}_{2}$ thin films with thickness of $410 \mathrm{~nm}$.

same in the films deposited at substrate temperature $673 \mathrm{~K}$ is $350 \mathrm{~nm}$. The increase in the substrate temperature leads to the increase in the grains size in the $\mathrm{CuInSe} \mathrm{S}_{2}$ thin films.

\subsection{Simultaneous TG-DTA study of CuInSe 2 bulk}

Simultaneous TG-DTA studies on CuInSe 2 bulk compound were carried out in the nitrogen atmosphere at the heating rate of $10{ }^{\circ} \mathrm{C} / \mathrm{min}$ and is shown in Fig. 8. From TG analysis it seems that the drastic weight loss occurs around $986^{\circ} \mathrm{C}$, 


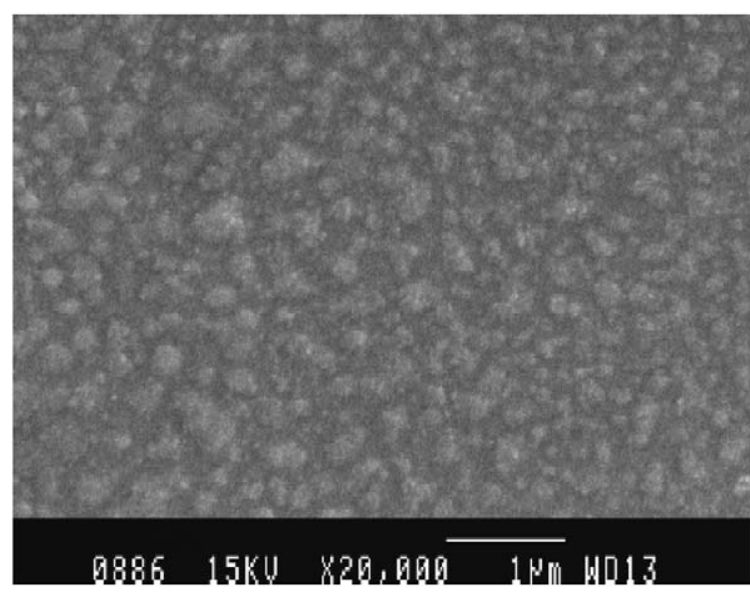

Fig. 7. SEM micrographs of the $\mathrm{CuInSe}_{2}$ thin films with thickness of $410 \mathrm{~nm}$ deposited with substrate temperature $673 \mathrm{~K}$.

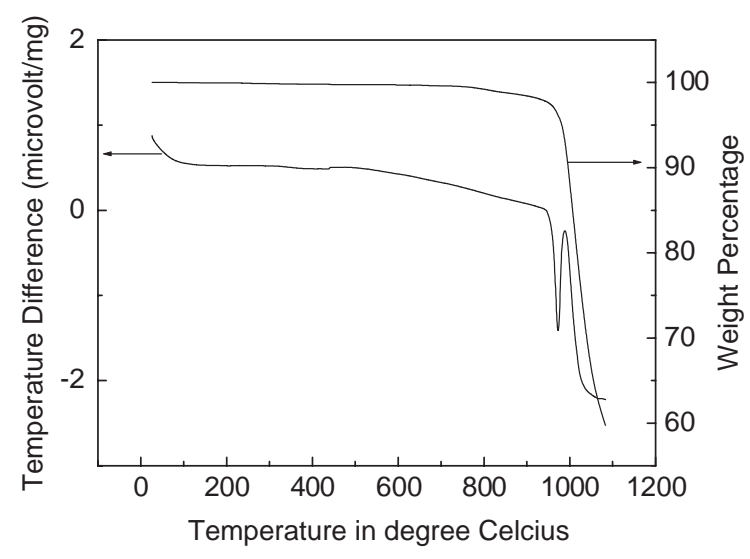

Fig. 8. Simultaneous TG-DTA plot of $\mathrm{CuInSe}_{2}$ bulk compound.

which is the melting point of the $\mathrm{CuInSe}_{2}$ compound. At the same time DTA curve gives an endothermic peak [15]. Since there is a drastic weight loss around the melting point of the compound, there may be the transformation of solid phase to vapour phase.

\subsection{Optical properties}

The transmittance spectra of $\mathrm{CuInSe}_{2}$ thin films of different thickness deposited at three different substrate temperatures 370,523 and $673 \mathrm{~K}$ are shown in Figs. 9-11. All the deposited $\mathrm{CuInSe}_{2}$ thin films show good transmittance and exhibited interference pattern in the region of the spectrum where the thin film is transparent. The transmittance spectrum exhibits oscillatory behaviour due to interference pattern between the wave fronts reflected from the two surfaces of thin film [16].

The absorption co-efficient $(\alpha)$ has been determined and is found to be of the order of $10^{4} \mathrm{~cm}^{-1}$. This is in good agreement with the earlier reports

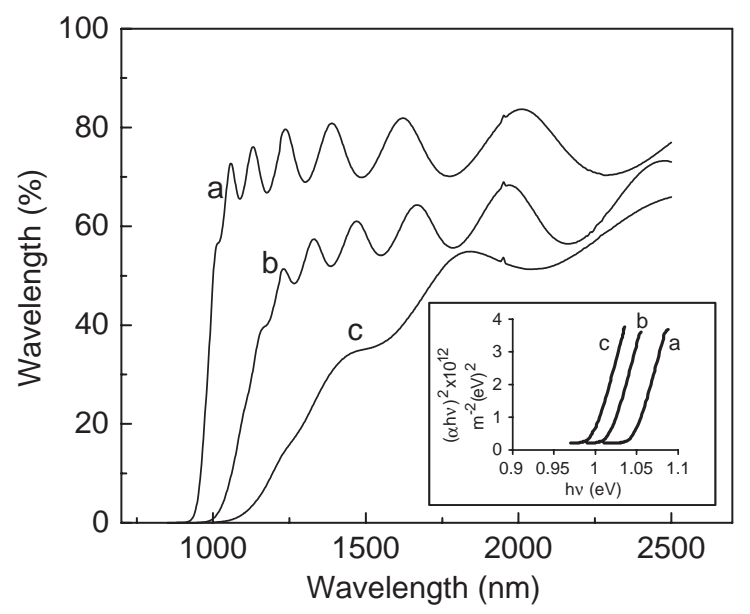

Fig. 9. The transmittance spectra of $\mathrm{CuInSe}_{2}$ thin films of different thickness deposited at substrate temperatures $370 \mathrm{~K}$.

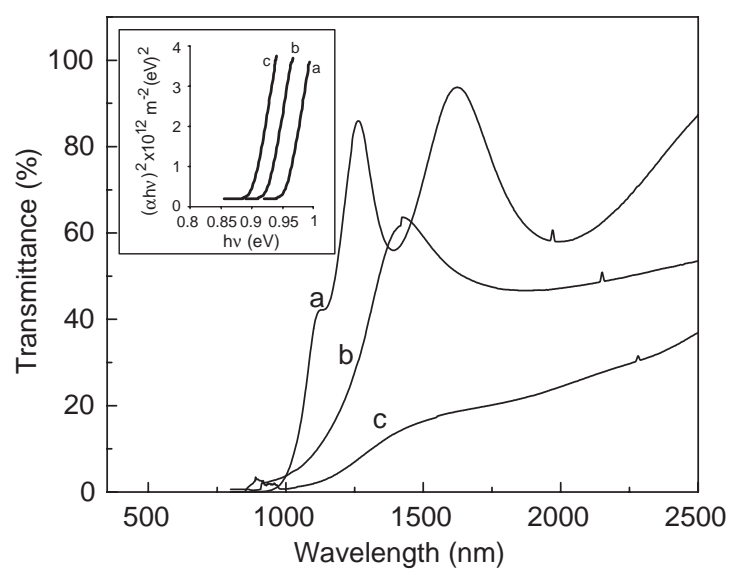

Fig. 10. The transmittance spectra of $\mathrm{CuInSe}_{2}$ thin films of different thickness deposited at substrate temperatures $450 \mathrm{~K}$. 


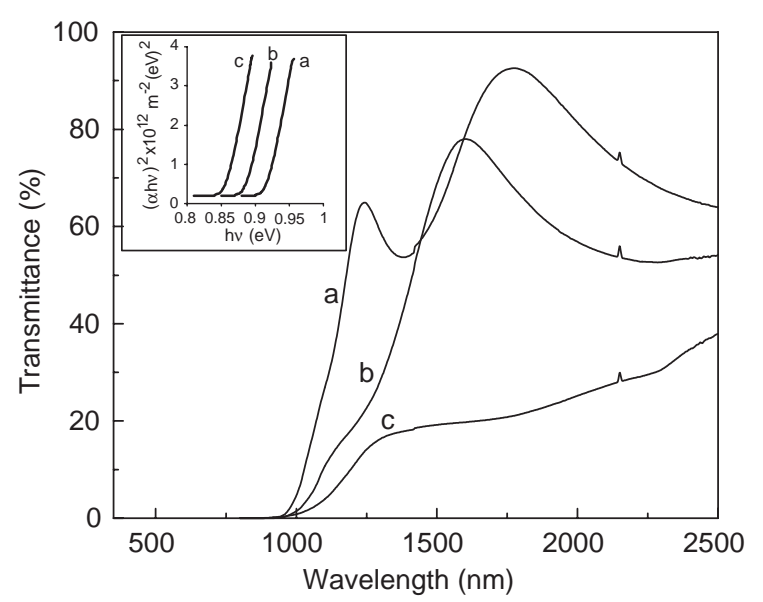

Fig. 11. The transmittance spectra of $\mathrm{CuInSe}_{2}$ thin films of different thickness deposited at substrate temperatures $673 \mathrm{~K}$.

[17-19]. The electronic transition between the valance and conduction bands can be direct or indirect.

In these two cases, the transition of electron can be allowed as permitted by the transition probability $(p)$ or forbidden where no such probability exists. The transition probability is given by

$(\alpha h v)^{p}=A\left(h v-E_{\mathrm{g}}\right)$,

where $E_{\mathrm{g}}$ denotes the band gap, $h v$ the energy of the incident photon and $A$ is a constant. The exponent $p$ is a number which characterizes the transition process.

The nature of transition in the film can be determined by plotting $(\alpha h v)^{p}$ against photon energy $h v$ for suitable valule of $p$ which yields straight line behaviour. The band gap $E_{\mathrm{g}}$ is determined by plotting $(\alpha h v)^{p}$ against photon energy $h v$ for suitable value of $p$ the graph is a straight line and the value of $E_{\mathrm{g}}$ is obtained by extrapolating the linear portion of the graph to intercept the photon energy axis.

Since there are no straight line behaviour in the plots for $(\alpha h v)^{2 / 3}$ versus $h v$ (direct forbidden), $(\alpha h v)^{1 / 2}$ versus $h v$ (indirect allowed), $(\alpha h v)^{1 / 3}$ versus $h v$ (indirect forbidden), the type of transition is neither direct forbidden nor indirect.

The presence of a single slope in the curves in the plot of $(\alpha h v)^{2}$ versus $h v$ of $\mathrm{CuInSe}_{2}$ thin
Table 1

Optical band gap of hot wall-deposited $\mathrm{CuInSe}_{2}$ thin films of different thicknesses at three different substrate temperatures

\begin{tabular}{llll}
\hline $\begin{array}{l}\text { Thickness of the } \\
\text { film }\end{array}$ & \multicolumn{3}{l}{ Band Gap of $\mathrm{CuInSe}_{2}$ thin films } \\
\cline { 2 - 4 } & $\begin{array}{l}\text { Substrate } \\
\text { temp. at } \\
370 \mathrm{~K}\end{array}$ & $\begin{array}{l}\text { Substrate } \\
\text { temp. at } \\
523 \mathrm{~K}\end{array}$ & $\begin{array}{l}\text { Substrate } \\
\text { temp. at } \\
673 \mathrm{~K}\end{array}$ \\
\hline 415 & 1.04 & 0.956 & 0.916 \\
555 & 1.015 & 0.923 & 0.885 \\
760 & 0.995 & 0.895 & 0.85 \\
\hline
\end{tabular}

films suggests that all the films are single phase in nature with direct-allowed transition. This type of transition has been reported already by previous researchers on $\mathrm{CuInSe}_{2}$ thin films [19-25]. The energy gap of the films has been determined by extrapolating the linear segment of the plots drawn for $(\alpha h v)^{2}$ versus $h v$ to the energy axis.

Table 1 gives the optical band gap of hot walldeposited $\mathrm{CuInSe}_{2}$ thin films of different thicknesses deposited at three different substrate temperatures. The range of optical band gap is found to lie between 0.85 and $1.04 \mathrm{eV}$. The band gap values of this study are in good agreement with the band gap values as reported by many earlier workers on $\mathrm{CuInSe}_{2}$ thin films [13,19,22,26-28]. Fig. 12 clearly shows that as thickness of the film increases the optical band gap decreases. The decrease in energy band gap with the thickness may be attributed to an increase in particle size and decrease in strain and dislocation density. This can be further explained from the three-dimensional quantum size effect leading to a decrease of band gap with increase of particle size, which is well known for colloidal semiconductors.

The variation of optical band gap of $\mathrm{CuInSe}_{2}$ thin films with substrate temperature is shown in Fig. 13. Films deposited at higher substrate temperatures are found to have lower band gap. This may be due to the sharp edges in the crystalline films. The decrease of band gap with the increase of substrate temperature is likely to be attributed to an increase of particle size and decrease in strain. 


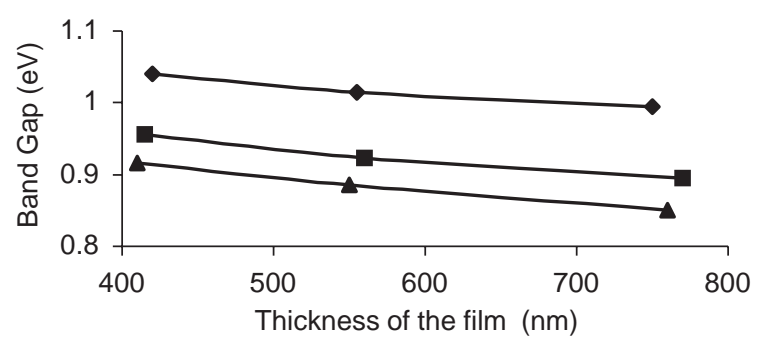

$\longrightarrow$ at sub. temp. $370 \mathrm{~K} \quad \longrightarrow$ at sub. temp. 523K

Fig. 12. The dependence of optical band gap of $\mathrm{CuInSe}_{2}$ thin films with the thickness of the film.

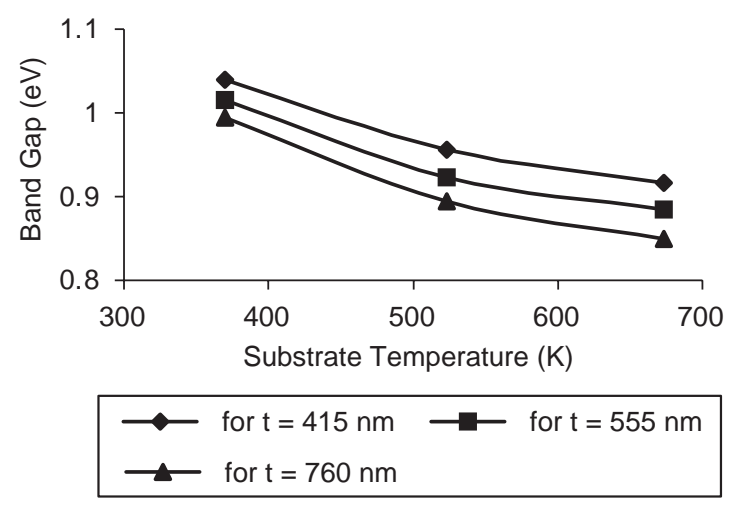

Fig. 13. The dependence of optical band gap of $\mathrm{CuInSe}_{2}$ thin films with the substrate temperature.

The refractive index of the films has been calculated using the formula [29]

$T=\left[64 n_{\mathrm{o}}^{2} n_{\mathrm{s}}^{2}\left(n^{2}+k^{2}\right)\right] /\left[a_{1} \exp (b)+a_{2} \exp (-b)\right]$

by iterative method. Here

$$
\begin{aligned}
a_{1}= & 2\left\{\left(n_{\mathrm{o}}+n\right)^{2}+k^{2}\right\}\left\{\left(n_{\mathrm{s}}^{2}+n_{\mathrm{o}}^{2}\right)\left(n_{\mathrm{s}}^{2}+n^{2}+k^{2}\right)\right. \\
& \left.+\left(4 n n_{\mathrm{o}} n_{\mathrm{s}}^{2}\right)\right\}, \\
a_{2}= & 2\left\{\left(n_{\mathrm{o}}-n\right)^{2}+k^{2}\right\}\left\{\left(n_{\mathrm{s}}^{2}+n_{\mathrm{o}}^{2}\right)\left(n_{\mathrm{s}}^{2}+n^{2}+k^{2}\right)\right. \\
& \left.-\left(4 n n_{\mathrm{o}} n_{\mathrm{s}}^{2}\right)\right\}, \\
b= & {[4 \pi k t] / \lambda, }
\end{aligned}
$$

where $n_{0}$ and $n_{\mathrm{s}}$ are the refractive indices of the air and of the substrate respectively. The refractive index $n$ of the films has been determined from the transmittance value $T$, by fitting the experimental curves in the above relation. The variation of refractive index of the hot wall-deposited $\mathrm{CuInSe}_{2}$ thin films of different thickness with the wavelength of the incident photon have been determined and shown in Fig. 14. Since the refractive index of the film is highly depending on transmittance of light incident over the film, a wavy pattern in the refractive index is observed [30].

The refractive index of the $\mathrm{CuInSe}_{2}$ thin film with the thickness $420 \mathrm{~nm}$ is found to lie in the range from 2 to 2.58 . This is in good agreement with the reported values of Dhanam et al. [31]. The refractive index of $\mathrm{CuInSe} \mathrm{In}_{2}$ thin film with the thickness $750 \mathrm{~nm}$ is found to decrease with the increase of incident photon wavelength. Decrease in refractive index is attributed to the strong effect of surface and volume imperfection on microscopic scale [32-34]. The refractive index of the $\mathrm{CuInSe}_{2}$ thin films is found to increase with the thickness of the film [35].

Fig. 15 gives the dependence of extinction coefficient with the wavelength of the incident photon. No monotonic change is observed in the extinction coefficient of hot wall-deposited

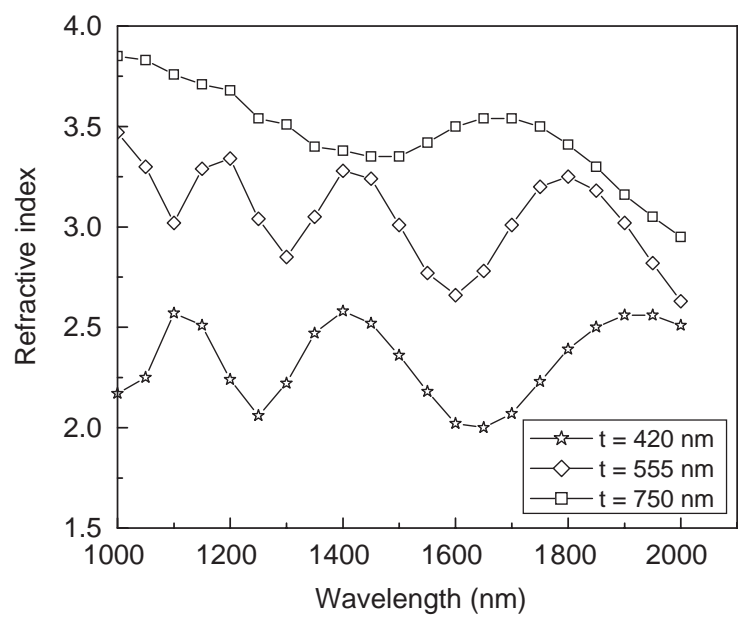

Fig. 14. The variation of refractive index of the hot walldeposited $\mathrm{CuInSe}_{2}$ thin films of different thickness with the wavelength of the incident photon. 


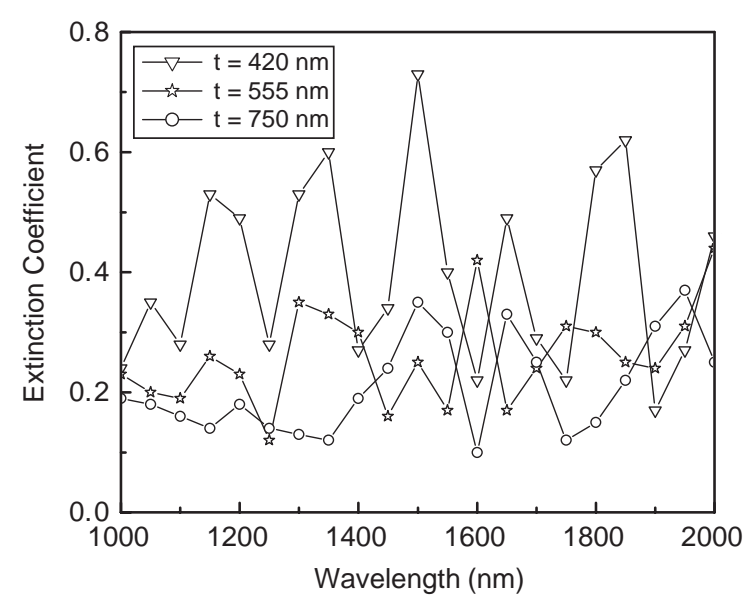

Fig. 15. The dependence of extinction coefficient of hot walldeposited $\mathrm{CuInSe}_{2}$ thin films of different thickness with the wavelength of the incident photon.

$\mathrm{CuInSe}_{2}$ thin film with the wavelength [30]. It is found that the extinction coefficient of hot walldeposited $\mathrm{CuInSe}{ }_{2}$ thin films is decreasing with the increase of thickness of the film.

\section{Conclusion}

$\mathrm{CuInSe}_{2}$ thin films were prepared on to wellcleaned glass substrates by hot wall deposition technique and they are polycrystalline in nature, single phase and exhibiting chalcopyrite structure. The crystallites were found to have a preferred orientation along the (112) direction. As the substrate temperature increases the grain size increases. An endothermic reaction is observed near the melting point of the compound in simultaneous TG-DTA analysis. As the thickness of the $\mathrm{CuInSe} \mathrm{I}_{2}$ thin film increases the optical band gap decreases and also as the substrate temperature increases, the optical band gap decreases. The refractive index of the $\mathrm{CuInSe}$ thin films are found decreasing with the incident photon wavelength.

\section{Acknowledgement}

One of the authors (S.A.) expresses his gratitude to "Tamil Nadu State Council for Science and
Technology-Chennai" for the award of "Young Scientist Fellowship" to him. The Management and Principal of Coimbatore Institute of Technology, Head and Staff members of Department of Physics, CIT -Coimbatore are being acknowledged.

\section{References}

[1] A.V. Postnikov, M.V. Yakushev, Thin solid films 451-452 (2004) 141.

[2] V.K. Gandotra, K.V. Ferdinand, C. Jagadish, A. Kumar, P.C. Mathur, Phys. Stat. Sol.(a) 98 (1986) 595.

[3] K.L. Chopra, S.R. Das, Thin Film Solar Cells, Plenum, New York, 1983, p. 417.

[4] I. Konovalov, Thin solid films 451-452 (2004) 413.

[5] J. Diekoszewsk, J.J. Loferski, R. Beaulieu, Sol. Energy Mater. 2 (1980) 363.

[6] F.R. White, A.H. Clark, M.C. Graf, S.P. Grindle, L.L. Kazmerski, J. Vac.Sci.Technol. 16 (1979) 287.

[7] C.D. Lokhande, G. Hodes, Sol. Cells 21 (1987) 215.

[8] R.A. Mickelson, B.J. Stanbery, J.E. Avery, W.S. Chen, W.E. Devancy, in: Proceedings Of the 19th IEEE Photovoltaic Specialists Conference, 1987, p. 744.

[9] M.D. Kannan, R. Balasundaraprabhu, S. Jayakumar, P. Ramanathasamy, Sol. Energy Mater. Sol. Cells 81 (2004) 379.

[10] D. Schikora, H. Sitter, J. Humen Berger, K. Lischka, Appl. Phys. Lett. 48 (1986) 1276.

[11] K. Senthil, D. Nataraj, K. Prabakar, D. Mangalaraj, Sa.K. Narayandass, N. Udhayakumar, N. Krishnakumar, Mater. Chem. Phys. 58 (1999) 221.

[12] M. Nishitani, T. Negami, M. Terauchi, T. Hirao, Jpn. J. Appl. Phys. 31 (1992) 192.

[13] R. Pal, K.K. Chattopadhya, S. Chandhuri, A.K. Pal, Sol. Energy Mater. Sol. Cells 33 (1994) 241.

[14] Yoshio Hachiuma, Atsushi Ashida, Nobuyuju Yamamoto, Taichiro Ito, Yoshio Cho, Sol. Energy Mater. Sol. Cells 35 (1994) 247.

[15] A. R. West, Solid State Chemistry And its Applications, Wiley and SEA, p. 102-108.

[16] J.C. Manifacier, M. Demusica, J.P. Fillard, L. Vicario, Thin Solid Films 41 (1997) 127.

[17] N. Kavcar, M.J. Carter, R. Hill, Sol. Energy Mater. Sol. Cells 27 (1992) 13.

[18] S. Isomura, H. Hayashi, S. Shirakata, Sol. Energy Mater. 18 (1989) 179.

[19] K.K. Chattopadhyay, I. Sanyal, S. Chauduri, A.K. Pal, Vacuum 42 (1991) 915.

[20] T. Tanaka, A. Wakahare, A. Yoshida, J. Appl. Phys. 87 (2000) 3283.

[21] S.N. Sahu, R.D. Kristensen, D. Haneman, Sol. Energy Mater. Sol. Cells 18 (1989) 385 . 
[22] A. Zegadi, D.M. Bagnall, A. Belattar, R.D. Pilkington, M.A. Slifkin, A.E. Hill, R.D. Tomlinson, Thin Solid Films 226 (1993) 248.

[23] A. Gupta, S. Shirakatata, S. Isomura, Sol. Energy Mater. Sol. Cells 32 (1994) 137.

[24] G. Masse, K. Guenoun, K. Djessas, F. Gustavino, Thin Solid Films 293 (1997) 45.

[25] W. Horig, H. Newmann, H. Sobotta, B. Schumann, G. Kuhn, Thin Solid Films 48 (1978) 67.

[26] J. Schmidt, H.H. Roscher, R. Labusch, Thin Solid Films 251 (1994) 116.

[27] T. Yamaguchi, J. Matsufusa, A. Yoshida, Sol. Energy Mater. Sol. Cells 27 (1992) 25

[28] S.I. Castaneda, F. Rueda, Thin Solid Films 361 (2000) 145.
[29] W. Horig, H. Newmann, H. Sobotta, B. Schumann, G. Kuhn, Thin Solid Films 48 (1978) 67.

[30] S. Senthilarasu, S. Velumani, R. Sathyamoorthy, A. Subbarayan, J.A. Ascencio, G. Canizal, P.J. Sebastian, J.A. Chavez, R. Perez, Appl. Phys. A 77 (2003) 383.

[31] M. Dhanam, R. Balasundaraprabhu, S. Jayakumar, P. Gopalakrishnan, M.D. Kannan, Phys. Stat. Sol. (a) 191 (2002) 149.

[32] J.M. Pawlikowwski, Thin Solid Films 127 (1985) 39.

[33] K. Ehshan, S.G. Tomlin, J. Phys. D 8 (1975) 581.

[34] J.C. Manifacier, J. Gasiot, J.P. Filliard, J. Phys. E 9 (1976) 1002.

[35] G. Aren, V.D. Vankar, O.P. Agnihotri, J. Appl. Phys. 72 (1992) 3659. 